Article

\title{
SxtA and sxtG Gene Expression and Toxin Production in the Mediterranean Alexandrium minutum (Dinophyceae)
}

\author{
Federico Perini 1, Luca Galluzzi 1, Carmela Dell'Aversano ${ }^{2}$, Emma Dello Iacovo ${ }^{2}$, \\ Luciana Tartaglione ${ }^{2}$, Fabio Ricci ${ }^{1}$, Martino Forino ${ }^{2}$, Patrizia Ciminiello ${ }^{2}$ \\ and Antonella Penna ${ }^{1, *}$
}

1 Department of Biomolecular Sciences, University of Urbino, Viale Trieste 296, Pesaro 61121, Italy; E-Mails: federico.perini@uniurb.it (F.P.); luca.galluzzi@uniurb.it (L.G.); fabio.ricci@uniurb.it (F.R.)

2 Department of Pharmacy, University of Naples Federico II, Via D. Montesano 49, Naples 80131, Italy; E-Mails: dellaver@unina.it (C.D.); emma.delloiacovo@unina.it (E.D.I.); luciana.tartaglione@unina.it (L.T.); forino@unina.it (M.F.); ciminiel@unina.it (P.C.)

* Author to whom correspondence should be addressed; E-Mail: antonella.penna@uniurb.it; Tel.: +39-0722-304908; Fax: +39-0722-304902.

External Editor: Andrea Bourdelais

Received: 23 July 2014; in revised form: 23 September 2014 / Accepted: 15 October 2014 / Published: 22 October 2014

\begin{abstract}
The dinoflagellate Alexandrium minutum is known for the production of potent neurotoxins affecting the health of human seafood consumers via paralytic shellfish poisoning (PSP). The aim of this study was to investigate the relationship between the toxin content and the expression level of the genes involved in paralytic shellfish toxin (PST) production. The algal cultures were grown both in standard $\mathrm{f} / 2$ medium and in phosphorus/nitrogen limitation. In our study, LC-HRMS analyses of PST profile and content in different Mediterranean A. minutum strains confirmed that this species was able to synthesize mainly the saxitoxin analogues Gonyautoxin-1 (GTX1) and Gonyautoxin-4 (GTX4). The average cellular toxin content varied among different strains, and between growth phases, highlighting a decreasing trend from exponential to stationary phase in all culture conditions tested. The absolute quantities of intracellular $\operatorname{sxtAl}$ and $\operatorname{sxt} G \mathrm{mRNA}$ were not correlated with the amount of intracellular toxins in the analysed A. minutum suggesting that the production of toxins may be regulated by post-transcriptional mechanisms and/or by the concerted actions of alternative genes belonging to the PST biosynthesis gene cluster. Therefore, it is likely that the $s x t A 1$ and $s x t G$ gene expression
\end{abstract}


could not reflect the PST accumulation in the Mediterranean A. minutum populations under the examined standard and nutrient limiting conditions.

Keywords: Alexandrium minutum; dinoflagellate; gene expression; genomics; HAB (harmful algal bloom); PST (paralytic shellfish toxin); saxitoxin; qPCR

\section{Introduction}

Dinoflagellates are unicellular protists that play important ecological roles in marine and freshwater habitats. Approximately 2000 species of dinoflagellates are known to date, most of which are found in marine habitats $[1,2]$. In the marine environment, they are important primary producers, both as free living phytoplankton and symbionts of reef forming corals or other animals [3]. Dinoflagellates also produce a wide variety of secondary metabolites including a diverse array of toxins that have a significant impact on marine ecosystems and fisheries. Almost 100 species have been identified as producers of toxic compounds that can affect humans through the trophic chain $[4,5]$.

Nearly all the classical seafood poisoning syndromes, paralytic- (PSP), diarrhetic- (DSP), neurotoxic- (NSP), azaspiracid shellfish poisoning (AZP), and ciguatera fish poisoning (CFP), are caused by dinoflagellate toxins. One exception is represented by amnesic shellfish poisoning (ASP), which is caused by the diatomean toxin, domoic acid [6]. In addition to the classic seafood toxins, dinoflagellates may produce a range of other biologically active compounds, including cytotoxins, antibiotics and immunosuppressant compounds [7-9].

Saxitoxin and its analogues are potent environmental neurotoxins that can cause a severe human illness named paralytic shellfish poisoning (PSP) syndrome due to consumption of vector species, such as mussels, clams and oysters [10,11], which mainly accumulate toxins in their digestive glands. The PSP syndrome is the most widespread harmful algal bloom (HAB)-related shellfish poisoning illness [6]. It has serious impacts on human health, the marine trophic chain, marine mammals, fish, and seabirds, wild and cultured seafood, tourism and recreational activities. Dinoflagellates belonging to the genus Alexandrium are reported to be the main biogenetic source of PSP toxins. Indeed, these toxins are also produced by Gymnodinium catenatum and Pyrodinium bahamense, as well as by several genera of predominantly freshwater cyanobacteria [12,13]. Members of the genus Alexandrium are widespread globally [14]. In particular, in the Mediterranean Sea, the diversity of Alexandrium appears to be higher than elsewhere (12 distinct species have been identified so far from this sea) [15]. Moreover, Alexandrium biogeography is characterized by the distribution of toxic and non-toxic strains of the same species, or of closely related species [16]. From a chemical standpoint, PSP toxins are tetrahydropurine derivatives that include carbamoyl toxins, namely saxitoxin (STX), neosaxitoxin (NEO), gonyautoxins (GTX1 to GTX4), N-sulfocarbamoyl toxins (C1-C4, B1, and B2), and decarbamoyl toxins (dcSTX, dcNEO, and dcGTX1 to dcGTX4). A number of minor derivatives of STX have been reported both from microalgae [17] and seafood [18].

The biosynthetic pathway and genes responsible for STX synthesis have been recently identified in the cyanobacterial species Cylindrospermopsis raciborskii, Anabaena circinalis, Aphanizomenon spp., Raphidiopsis brookii, Lyngbya wollei and Scytonema sp. [19-24]. SxtA is the unique starting gene of 
the STX-synthesis in cyanobacteria. This gene has a polyketide synthase (PKS)-like structure characterized by four catalytic domains with predicted activities of a $S$-adenosyl-methionine- (SAM) dependent methyltransferase ( $s x t A 1)$, GCN5-related $N$-acetyltransferase (sxtA2), acyl carrier protein (sxtA3) and a class II aminotransferase (sxtA4) [19]. In both eukaryote and prokaryote organisms, STX appears to be synthesized by similar processes; in fact, incorporation patterns of precursors (as arginine, acetate and methionine) and toxin stereochemistry are identical in both cyanobacteria and dinoflagellates [25-27].

In recent years, $A$. minutum has been studied for identifying genes and expression patterns involved in critical pathways, such as those for toxin production [28]. To identify sxt genes from two STX-producing Alexandrium species, A. minutum and A. fundyense, different molecular approaches were applied using high-throughput sequencing technology of a large number of transcripts, in silico transcriptome analyses, rapid amplification of cDNA ends (RACE), qPCR and conventional PCR coupled with Sanger sequencing. These multiple approaches successfully identified the genes required for STX-synthesis in dinoflagellates. This demonstrated that STX-synthesis is to be ascribed to dinoflagellates and not to co-cultured bacteria as previously hypothesized [29]. The Alexandrium spp. transcripts of the sxtA gene have the same domain structure as those from cyanobacterial homologs, but the dinoflagellate transcripts are monocistronic; they occur in multiple copies and contain typical dinoflagellate spliced-leader sequences. Furthermore, investigation of STX-producing and non-producing dinoflagellate strains of six species showed the presence of the sxtA gene and STX-synthesis, with exception of four $A$. tamarense strains for which $\operatorname{sxt} A$ was amplified without evidence of STX or derivatives [29].

Additionally, in the cyanobacteria, the product of polyketide synthase is the substrate for the amidinotransferase, encoded by the gene $s x t G$, which is proposed to incorporate an amidino group from an arginine molecule into the STX intermediate [30]. Recently, the characterization of the second core gene of the STX pathway in dinoflagellates, $\operatorname{sxt} G$, was performed [31].

The aim of this study was to investigate the relationship between toxin content and expression level of the sxtAl and sxtG genes in the Mediterranean A. minutum.

It is known that the production of toxins in some Alexandrium spp. can be influenced by nutritional conditions. In particular, low levels of nitrate cause the decrease of toxicity, while low levels of phosphorus increase it [32-35]. Therefore, we conducted experiments also in conditions of nutrient depletion to check how these conditions could affect the toxins produced in A. minutum isolated from the Mediterranean Sea and if these nutritional factors could affect the regulation of $\operatorname{sxt} A$ and $\operatorname{sxt} G$ gene expression.

\section{Results and Discussion}

\subsection{Toxin Content in Standard Condition}

Liquid chromatography coupled with high resolution mass spectrometry (LC-HRMS) was used to check the presence of all the major STX derivatives. The HILIC-MS/MS method for PSP toxins developed by Dell'Aversano et al., on a triple quadrupole MS [36] was slightly modified to make it suitable to HRMS detection. All the analyzed strains were found to produce only GTX1 and GTX4, 
which differ from each other only in stereochemistry at one chiral center. They were produced at higher levels in the exponential phase than in the stationary phase. The intracellular content of toxins varied among strains in the two growth phases $(p<0.05)$. The CBA57 strain turned out to be the most productive one $\left(\mathrm{GTX} 1+\mathrm{GTX} 4=3.45 \mathrm{fmol} \mathrm{cell}^{-1}\right.$ in the exponential phase, and GTX1 + GTX4 $=$ $1.77 \mathrm{fmol} \mathrm{cell}^{-1}$ in the stationary phase), while the CBA53 strain was the lowest productive one $\left(\mathrm{GTX} 1=0.04 \mathrm{fmol} \mathrm{cell}^{-1}\right.$ in the exponential phase, and GTX1 $=0.01 \mathrm{fmol} \mathrm{cell}^{-1}$ in the stationary phase). In the AMIB5 and CBA57 strains, the toxin content significantly declined during cell growth from the exponential to the stationary phases $(p<0.05)$. However, the decrease of GTXs content from the exponential to the stationary phase was also observed in the other two strains, although it was not statistically significant (Figure 1). In almost all the analyzed samples, the GTX4 concentration was higher than that of GTX1, with the exception of the CBA53 strain that produces only GTX1. In particular, in the exponential phase the content of GTX4 was three times higher than GTX1 in the AMIB5 and AMI2OL strains, and 4.5 times in the CBA57 strain. In the stationary phase, only the GTX4 declined significantly in the CBA57 strain and the same trend was observed in the other strains. In the Alexandrium strains, the composition of toxins is related to the phenotypic trait, but the amounts are variable among strains. Members of the A. minutum group (as well as A. ibericum, A. lusitanicum, A. angustitabulatum) produce primarily gonyautoxins, such as GTX1 and GTX4 [14,37]. Average cellular toxin content of toxigenic Alexandrium isolates varies considerably (up to an order of magnitude) among different growth phases and environmental regimes in batch cultures [38,39]. Moreover, the toxin content of Alexandrium strains isolated from the same geographical area can be extremely variable (from undetectable levels to $>100 \mathrm{fmol} \mathrm{cell}^{-1}$ of toxins) [36]. The GTXs toxin content and composition of the Mediterranean A. minutum strains used in this study was in agreement with the previous observations $[40,41]$.

Figure 1. Intracellular GTX1/4 content in the Mediterranean A. minutum strains during the exponential and stationary growth phases (means $\pm \mathrm{SD}, n=3$ ).

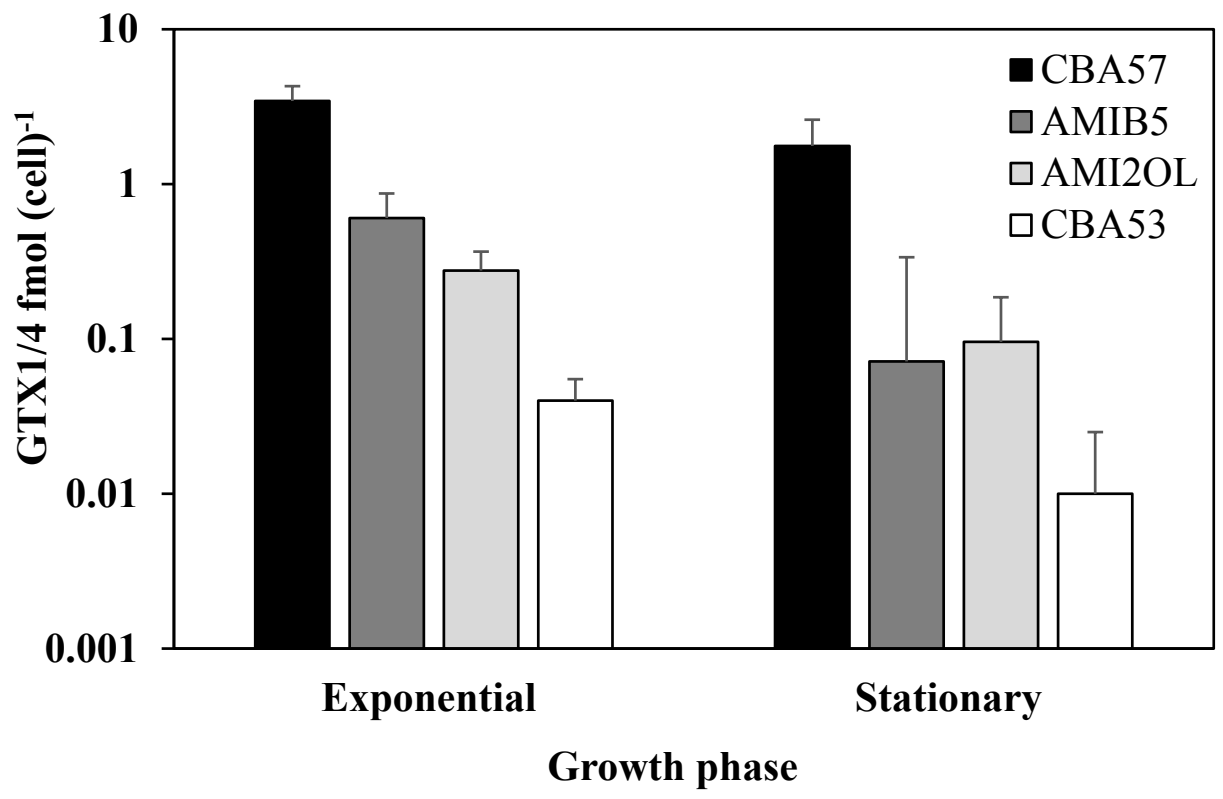




\subsection{The sxtA1 and sxtG Gene Expression in Standard Condition}

The use of endogenous housekeeping genes (actin or 5.8S rRNA) for relative quantification analyses did not produce reliable results due to the high expression variability of these genes between the two growth phases. Therefore, an absolute quantification approach was adopted using standard curves constructed with scalar dilutions of the sxtA1 and sxt $G$ PCR products. A fixed amount of human RNA was spiked in each reverse transcription reaction and human $\beta 2 \mathrm{M}$ gene transcript was amplified in each cDNA sample to control the efficiency of reverse transcription and to indicate possible inhibitory effects during the synthesis of the cDNA. Moreover, the $\beta 2 \mathrm{M}$ was also used as an exogenous housekeeping gene for relative quantification. Using this exogenous reference, the relative quantification data showed the same trend obtained with absolute quantification (data not shown). The sxtA1 and sxtG standard curves showed efficiency of $98 \%$ and $99 \%$ and good linear regression $\left(\mathrm{R}^{2}=0.99\right)$ (Supplementary Figure $\left.\mathrm{S} 1\right)$.

The number of $s x t A 1$ and $s x t G$ transcripts was calculated by plotting the $\mathrm{Ct}$ of each sample on the standard curve. The data were normalized per $\mu \mathrm{g}$ of total RNA (Figure 2).

Figure 2. The $s x t A 1$ and $s x t G$ gene expression in standard nutrient condition. Absolute quantification of $s x t A 1$ (A) and $s x t G$ mRNA (B) during the exponential and stationary phases of growth (means $\pm \mathrm{SD}, n=3$ ). The $s x t G$ expression was determined only in two strains of A. minutum (AMI2OL and AMIB5), the only ones for which the PCR amplification was confirmed with our specific primers using genomic DNA.
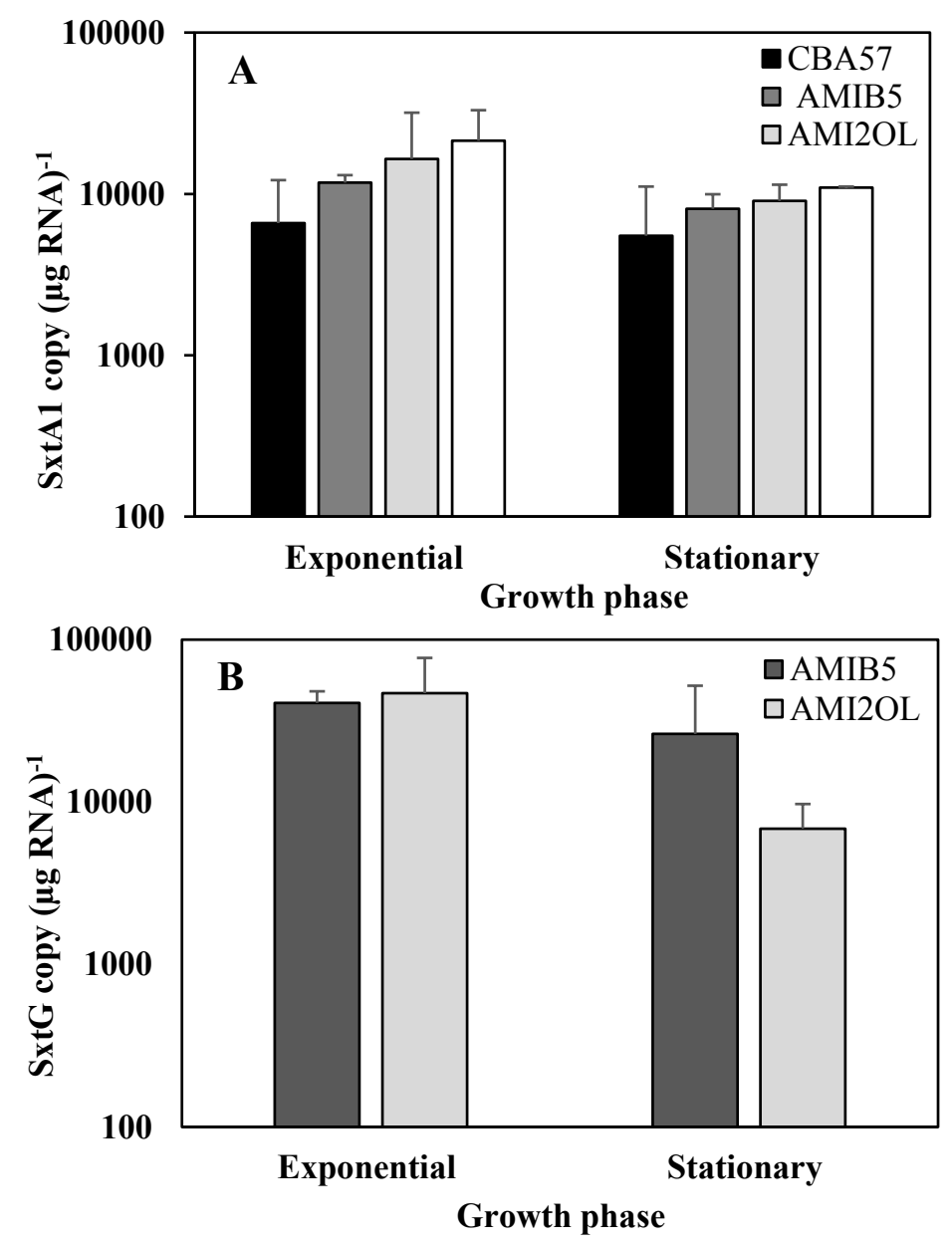
In the exponential phase, the CBA53 strain showed a content of the sxtA1 mRNA significantly higher than that of other strains $(p<0.05)$. Although a reduction of sxtA1 expression during the stationary phase compared to the exponential phase was evident for all strains; a statistically significant difference was observed only for the strain CBA53 $(p<0.05)$ (Figure 2A).

Curiously, the $\operatorname{sxt} G$ was not detected in the most toxic CBA57 strain, or in the CBA53 strain. This finding was also confirmed by experiments with internal positive control (see 3.4 in Experimental Section) demonstrating that the negative results was not an artifact due to inhibition of the PCR reactions. Therefore, the $\operatorname{sxt} G$ gene expression analyses were performed on AMI2OL and AMIB5 strains only. No significant differences of $\operatorname{sxt} G$ transcript abundance were observed between the two strains in both growth phases, but significant difference was found between the two growth phases in the AMI2OL strain $(p<0.05)$ (Figure 2B). Moreover, the $\operatorname{sxt} G$ expression did not correlate with sxtA1 gene expression in strains AMI2OL and AMIB5.

Unlike $s x t A$ gene, the presence of $\operatorname{sxt} G$ gene is not exclusively specific of the Alexandrium species reported to produce saxitoxins [31]. In fact, it was observed that the $s x t G$ amidinotransferase was present and transcribed in Alexandrium species where the sxtA gene and STX synthesis have not been identified [13]. Therefore, this gene could also be involved in other biochemical pathways or these Alexandrium spp. could have lost the capacity of STX synthesis [31]. In this study, the absence of sxt $G$ gene in CBA57 and CBA53 strains of A. minutum could be related to the presence of a homolog of amidinotransferase that was not amplified by our primers. In fact, a second dinoflagellate amidinotransferase that groups more distantly to $\operatorname{sxt} G$ with homologous actinobacterial and cyanobacterial cylindrospermopsin aoaA and cyrA sequences has been identified suggesting that multiple amidinotransferases have been acquired by horizontal gene transfer (HGT) in parallel or separate events during Alexandrium evolution [31].

Each amount of sxtAl or $s x t G$ mRNA measured in the two growth phases was compared to the amount of toxins (GTX1/4) produced. No significant correlations were found between amount of mRNAs and intracellular toxin content in all the strains. Unexpectedly, the less toxic CBA53 strain showed the highest level of sxtA1 gene expression. Moreover, the mRNA transcripts and toxins content were compared along the different growth phases. In all the strains, even if no significant correlation was found, the mRNA transcripts and toxins showed the highest and lowest contents in the exponential and stationary phases, respectively.

The absence of correlation between the gene expression and toxin content could be due to the fact that the PSP toxin biosynthesis enzymes are long-living enzymes with a slow turn-over and may be regulated by post-translational mechanisms [30]. Moreover, in the cyanobacteria C. raciborskii $\mathrm{T} 3$, the saxitoxin biosynthetic pathway is encoded by a gene cluster of more than $35 \mathrm{~kb}$, and comparative sequence analysis assigns 30 catalytic functions to 26 proteins [19]. A cluster of 14 genes, defined as "core" genes ( $x x t A-s x t I$, sxtP-sxtS and $s x t U)$ is common between the STX-pathways of several cyanobacterial genera [11,42]. Eight of these genes ( $s x t A, s x t B, s x t D, s x t G, s x t H / T, s x t I, s x t S$ and $s x t U$ ) seem to be directly implicated in STX-synthesis [19]. The STX biosynthesis pathway appears conserved between cyanobacteria and dinoflagellates: it involves arginine, SAM synthetase and acetate, with the addition of the methyl group of SAM into the final molecule [43]. It is likely that in A. minutum, saxitoxin and its derivatives are the result of the synergistic action of several enzymes homologous to those of cyanobacteria $[13,29]$. Of the 14 "core" STX genes, 10 dinoflagellate homologues, 
or candidate genes, are presently identified ( $s x t A, s x t B, s x t D, s x t F-I, s x t Q$, sxt $S$ and $s x t U$ ) $[29,44]$. However, sequence conservation might be so low that reliable homologue identification is impossible or, if several homologues are indeed missing in the dinoflagellates, alternative dinoflagellate genes could have substituted their functions in the SXT pathway. Alternatively, the STX biosynthetic pathway could have evolved independently in cyanobacteria and dinoflagellates [44]. Moreover, dinoflagellates have large genomes, a considerable number of unknown genes and a high frequency of repeats making genomic studies very hard [27].

Stüken et al. (2011) characterized the sxtA gene showing a comparable domain structure to its cyanobacterial homologue [29]. SxtA encodes a polyketide synthase, the first enzyme in the metabolic pathway, but it is not clear which other genes are involved and the extent of their activity. This fact is to be considered when the amount of intracellular toxins needs to be correlated to gene expression. Also, the subsequent characterization of $\operatorname{sxt} G$, the second "core" gene in the STX pathway [31], may indicate a massive transfer of toxin-related genes from bacteria to dinoflagellates [45]. However, in contrast to cyanobacteria, most of the genes involved in STX-synthesis in dinoflagellates have remained elusive.

\subsection{The sxtAl Gene Expression and Toxin Content under Phosphorus Limitation}

Strains of CBA57, AMI2OL and CBA53 were grown in phosphorus limitation as described in the Experimental Section. Under this condition, all strains were characterized by a short exponential phase; therefore, all withdrawals were made at the fifth or sixth day (exponential phase) and at the 12th day (stationary phase) (Supplementary Figure S2). The concentrations of dissolved inorganic phosphorus varied from $0.16 \pm 0.1 \mu \mathrm{M}$ (day 1) to $0.13 \pm 0.04 \mu \mathrm{M}$ (day 12) (Supplementary Table S1). The daily decrease in dissolved phosphorus is extremely low compared to the variation of the standard condition. This could be due to the fact that the algal biomass that develops in these limiting conditions is much lower compared to the standard conditions. In the phosphorus limitation, the toxin content tended to decrease from exponential to stationary phase confirming the same trend of the standard conditions (Figure 3A). However, this decrease was not significant with the exception of AMI2OL strain $(p<0.05)$.

Under phosphorus limitation, the $s x t A 1$ gene expression decreased significantly only in the CBA53 strain between the exponential and stationary phase. No significant variation of sxtA1 gene expression was observed in the AMI2OL strain (Figure 3B). Furthermore, in CBA57 strain, which expressed the lowest sxtAl copy number in the standard condition, the expression of sxtAl gene was undetectable in contrast to the higher GTX1/4 content respect to the other $A$. minutum strains.

The toxin content and mRNA levels at each stage of growth for all strains were compared with the values obtained in the standard growth condition. No significant differences of GTX1/4 content were observed between standard and phosphorous depletion for strains CBA53 and AMI2OL, while the CBA57 strain showed a significant toxin content decrease $(p<0.05)$ in phosphorous limitation both in exponential and stationary phases. It is noteworthy that in phosphorous depletion, GTX2 and GTX3 were detected in trace amounts in the CBA57 strain only (data not shown). 
Figure 3. Intracellular toxin content in the Mediterranean A. minutum strains during the exponential and stationary growth phases (means $\pm \mathrm{SD}, n=3$ ) (A) and sxtAl gene expression as mRNA copy per $\mu \mathrm{g} \mathrm{RNA}^{-1}$ (B) under phosphorus limitation (means $\pm \mathrm{SD}$, $n=3)$. The sxtA1 gene expression was undetectable in the CBA57; thus, sxtA1 copy $\left(\mu \mathrm{g} \mathrm{RNA}^{-1}\right)$ values were omitted.
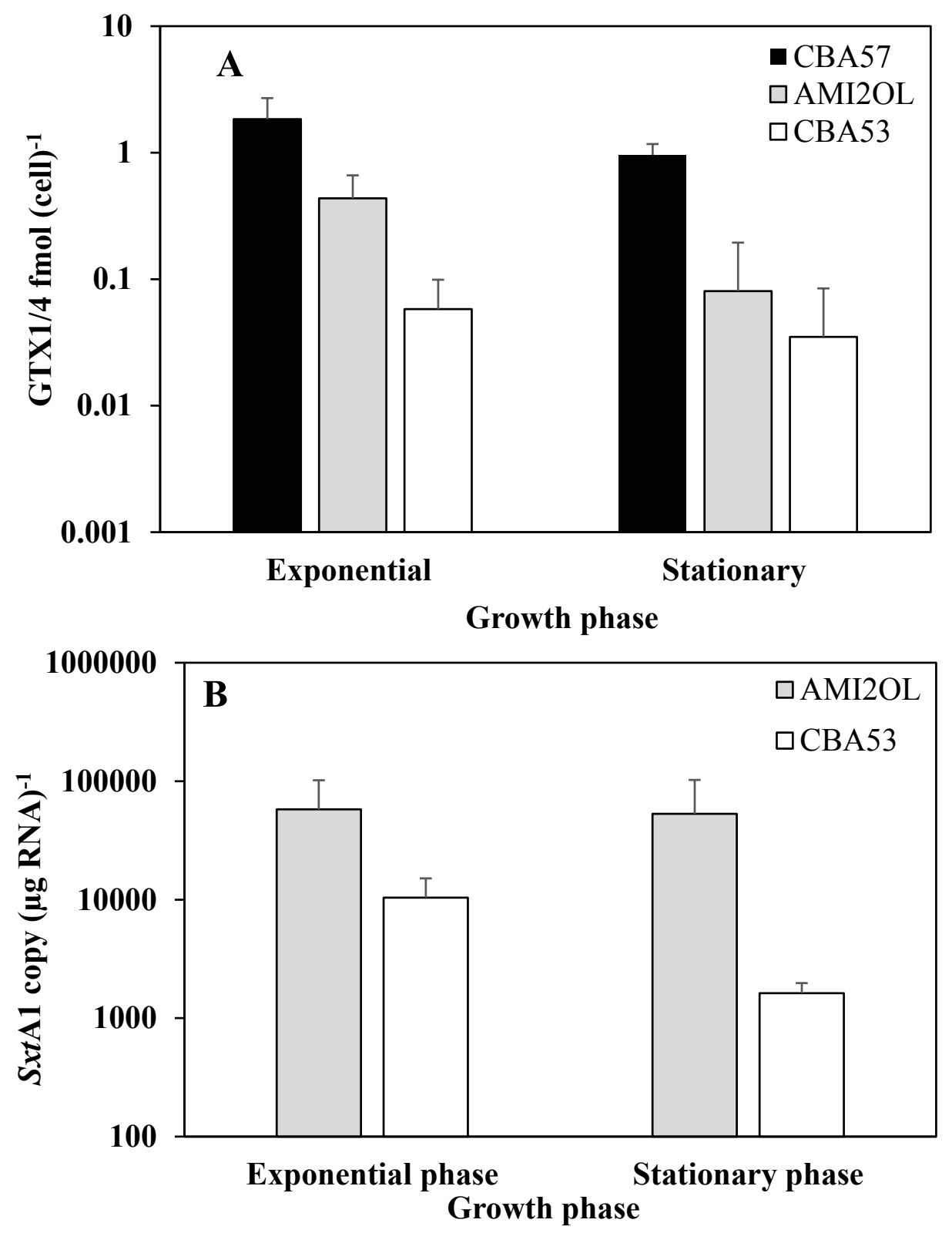

As for the sxtA1 gene expression, a significant decrease of the mRNAs was found in CBA53 strain compared to the standard nutritional condition. In particular, in the CBA57 strain, which expressed the lowest sxtAl copy number under the standard condition, the expression of sxtAl gene was undetectable along with an evident decreasing of toxins. Instead, in the AMI2OL strain, the sxtA1 gene expression did not vary much in both the exponential and stationary phases compared to the standard growth conditions. However, the Spearman's correlation analysis confirmed the independence of gene expression and GTX1/4 intracellular content for each strain. 
Some authors reported accumulation of intracellular PST in phosphorus limiting conditions [33-35,46,47]. However, in these studies, almost all the A. minutum strains were not from Mediterranean areas with the exception of the A. minutum A5 strain. This strain in the phosphorous limitation did not show significant effect on toxin production [47]. In that study, a rapid and substantial increase in PST levels was observed in A. minutum strains in the presence of waterborne grazers, suggesting that secondary metabolism of dinoflagellates is not only dependent on resource availability, but also on the predation pressure. In fact, it was also suggested that PSTs may be produced in phosphate-limited conditions in order to redirect the grazing pressure toward alternative non-toxic competitors [32]. In the nutritional conditions of our study, the strains were not subjected to pressure from predators. Furthermore, since phosphorus is involved in the energetic metabolism and in the regulation of intracellular functions, its deficiency in the medium should negatively affect the nucleotide synthesis, as well as the energy reserves of the cell. As a consequence, it is logical to suppose that cell energy is likely employed for the maintenance of basic and essential cellular functions [35]. Hence, the activation of energetically costly pathways, such as that used for saxitoxin synthesis, would not be activated if not necessary. This could explain the down-regulation of the sxtA1 gene in our Mediterranean A. minutum strains during phosphorus depletion treatment. The different behaviour of the A. minutum AMI2OL could be due to the biological/genetic variability of the strain [48], and this has to be further investigated by using a higher number of Mediterranean A. minutum strains.

\subsection{The sxtA1 Gene Expression and Toxin Content under Nitrogen Limitation}

The sxtA1 gene expression under nitrogen limitation was tested on the CBA57 and AMIB5 strains. As observed for A. minutum strains grown in phosphorus limitation, the growth was characterized by a short exponential phase; therefore, sample withdrawals were made at the fifth or sixth day (exponential phase) and the 12th day (stationary phase) (Supplementary Figure S2). The concentration of total dissolved nitrogen varied from $77.5 \pm 6.5 \mu \mathrm{M}$ at the inoculation time to $0.73 \pm 0.1 \mu \mathrm{M}$ at day 12 (Supplementary Table S1).

Both strains produced similar toxin amounts in exponential and stationary phases with no significant differences (Figure 4A). For the CBA57 strain, a significant reduction in toxin intracellular content was found in both exponential and stationary phases with respect to the standard conditions $(p<0.05)$, while in the AMIB5 strain this difference was not significant. In the CBA57 strain, the sxtAl gene was constantly expressed under nitrogen limitation, either in the exponential and stationary phase (Figure 4B). In the AMIB5 strain, the sxtA1 expression was strongly down regulated in the stationary phase. With respect to the standard conditions, expression of sxtAl in strain CBA57 did not change significantly, while it was strongly down regulated in the AMIB5 strain $(p<0.05)$.

The effect of nitrogen limitation in toxin production by the CBA57 strain was consistent with previous studies $[35,47]$. This effect is reasonable because toxins are nitrogen-rich molecules, which might be synthesized as a by-product of amino acids or nitrogen excess. In fact, in nitrogen limitation conditions, the intra-cellular pools of nitrogen would mainly be allocated to the production of nucleotides and amino acids in order to maintain basic and essential cellular functions, while the activation of nitrogen demanding metabolic pathways, such as PST biosynthesis, would not be 
favoured [46]. On the other hand, the fact that intracellular content of GTX1/4 did not change significantly with respect to the standard conditions in AMIB5 may be due to low amounts of toxin production. In this case, the amount of nitrogen in the medium may be sufficient to maintain the toxin levels observed in the standard conditions.

Figure 4. Intracellular toxin content in the Mediterranean $A$. minutum strains during the exponential and stationary growth phases (means $\pm \mathrm{SD}, n=3$ ) (A) and sxtAl gene expression as mRNA copy per $\mu \mathrm{g} \mathrm{RNA}^{-1}$ (B) under nitrogen limitation (means $\pm \mathrm{SD}$, $n=3$ ). In the A. minutum AMIB5 strain, the sxtAl expression was not detected in the stationary phase.
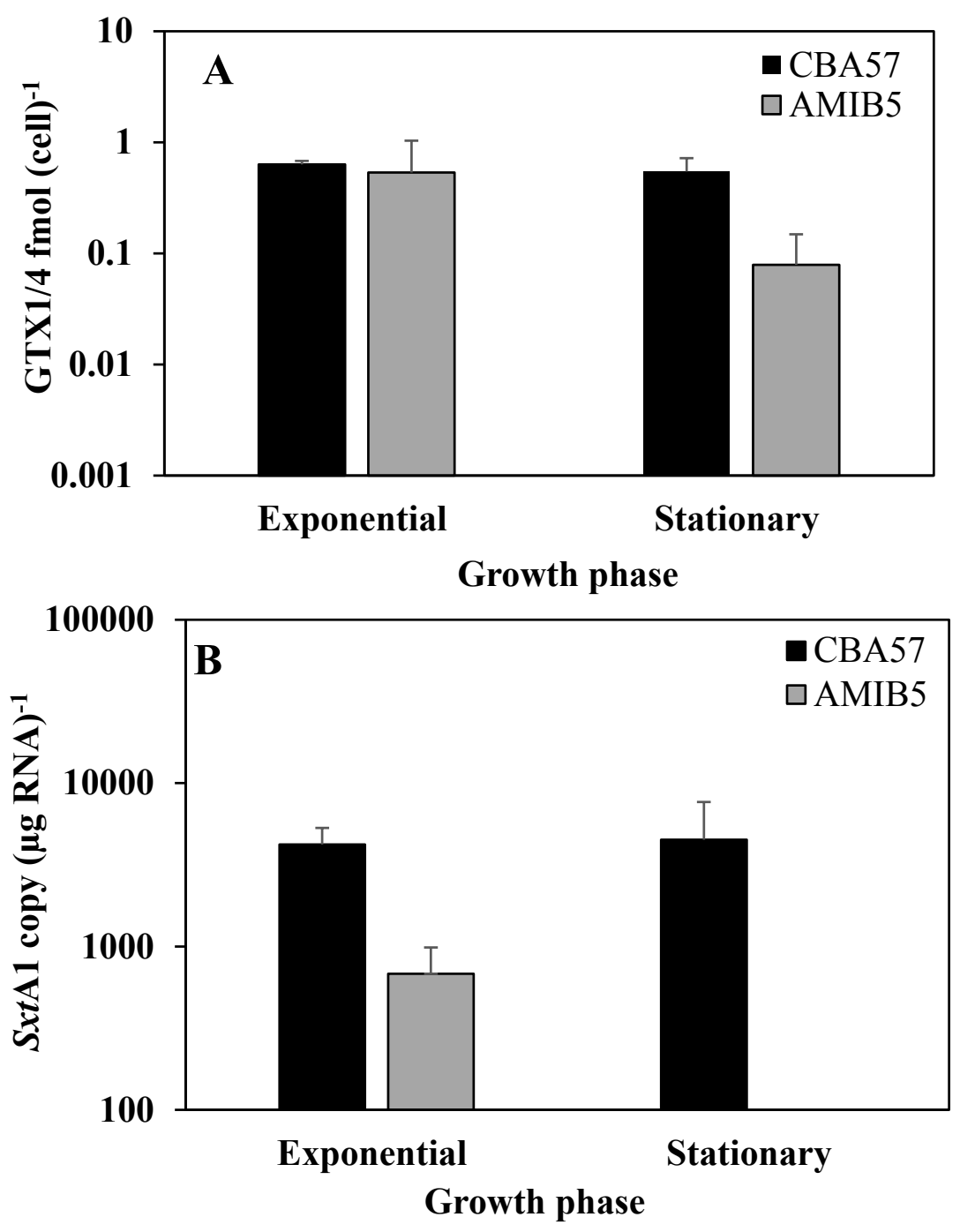

\section{Experimental Section}

\subsection{Strain Cultures}

Alexandrium minutum monoclonal strains used in this study were isolated from surface sea water in

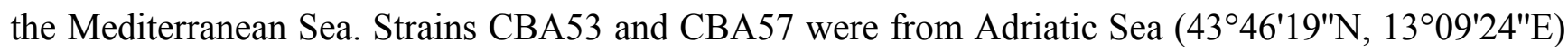
and AMIB5 and AMI2OL were from Ionian Sea $\left(37^{\circ} 03^{\prime} 04^{\prime \prime N}, 15^{\circ} 17^{\prime} 02^{\prime \prime} \mathrm{E}\right)$ and Tyrrhenian Sea $\left(40^{\circ} 57^{\prime} 11^{\prime \prime} \mathrm{N}, 09^{\circ} 39^{\prime} 04^{\prime \prime} \mathrm{E}\right)$, respectively. The sampled localities are mesotrophic areas. The localities of 
the Ionian Sea and Tyrrhenian Sea are closed areas characterized by freshwater inputs; the coastal north-western Adriatic Sea is strongly influenced by the Po river input determining the trophic conditions of seawaters $[49,50]$.

Cultures were maintained in $2 \mathrm{~L}$ bottles, using standard conditions of $\mathrm{f} / 2$ medium minus silicate [51], at $21.5 \pm 1{ }^{\circ} \mathrm{C}$, light irradiance of $100 \mu \mathrm{mol} \mathrm{m} \mathrm{m}^{-2} \mathrm{~s}^{-1}$ for $12: 12 \mathrm{~h}$ light-dark cycles. In addition to these standard conditions, CBA53 and AMI2OL strains were also cultured in phosphorus starvation, the strain AMIB5 in nitrogen starvation and strain CBA57 in both phosphorous and nitrogen starvation. The concentrations of nutrient and growth conditions are summarized in Table S1. Every two days each culture was assessed for cell concentrations and growth rate by Utermöhl method [52] using an inverted microscope (Axiovert 40 CFL, Zeiss, Göttingen, Germany).

The stock cultures to be further inoculated in batch cultures were grown with antibiotics $\left(50 \mu \mathrm{gL}^{-1}\right.$ ampicillin, $33 \mu \mathrm{g} \mathrm{mL}^{-1}$ gentamicin, $10 \mu \mathrm{g} \mathrm{mL}^{-1}$ ciprofloxacin, $1.13 \mu \mathrm{g} \mathrm{mL}^{-1}$ chloramphenicol and $0.025 \mu \mathrm{g} \mathrm{mL} \mathrm{m}^{-1}$ streptomycin sulphate) using sterile handling techniques to minimize bacterial influence, as described in [40]. The antibiotic treatment was stopped at inoculation of the cultures while always maintaining aseptic handling techniques to avoid any bias introduced by this handling. The cells were analysed in the exponential (growth rate $0.21 \pm 0.06 \mu$ day $^{-1}$ ) and stationary (growth rate $0.03 \pm 0.01 \mu \mathrm{day}^{-1}$ ) growth phases (Supplementary Figure S3). The duration of culture experiments was between 12 and 31 days, depending on the growth rates. Cells were harvested by filtration using $3 \mu \mathrm{m}$ pore-sized filters, rinsed with sterilised seawater and centrifuged $10 \mathrm{~min}$ at $1200 \times \mathrm{g}$. The pellets were immediately stored at $-80^{\circ} \mathrm{C}$ until total RNA extraction or PSP toxin analysis. The eluates were stored at $-20^{\circ} \mathrm{C}$ and used for the nutrient analyses.

\subsection{Toxin Analysis}

\subsubsection{Chemicals}

All organic solvents, glacial acetic acid, formic acid, and ammonium formate (Laboratory grade) were from Sigma-Aldrich Corporation (St. Louis, MO, USA). Standard solutions of PSP toxins were provided by the NRC Certified Reference Materials Program (Institute for Marine Biosciences, Halifax, NS, Canada). Nine concentration levels were prepared from a mixture of certified standards by serial dilutions in water $0.1 \mathrm{M}$ acetic acid, starting with the following concentrations: B1 (1370 ng/mL), C1 (1500 ng/mL), C2 (450 ng/mL), STX (340 ng/mL), GTX2 (1250 ng/mL), GTX3 (480 ng/mL), NEO (290 ng/mL), GTX1 (690 ng/mL), GTX4 (230 ng/mL), deSTX (590 ng/mL), dcGTX2 (1140 ng/mL), dcGTX3 (260 ng/mL), and dcNEO (280 ng/mL). A mixture containing the above toxins was also used to optimize HRMS parameters.

\subsubsection{Pellet Extraction}

Pellet of the four different strains of A. minutum (CBA53, CBA57, AMIB5 and AMIOL) were separately extracted. Each pellet was added of $1 \mathrm{~mL}$ aqueous $0.1 \mathrm{M}$ acetic acid and sonicate for $10 \mathrm{~min}$. in pulse mode, while cooling continuously in an ice bath. The mixture was centrifuged at $4835 \times \mathrm{g}$ for $10 \mathrm{~min}$ and the supernatant was decanted so as to obtain $1 \mathrm{~mL}$ extract that was directly analysed by LC-HRMS. 


\subsubsection{LC-HRMS}

All LC-HRMS analyses were performed on an Agilent 1100 LC binary system (Palo Alto, CA, USA) which included a solvent reservoir, in-line degasser, binary pump and refrigerated autosampler coupled to a hybrid linear ion trap LTQ Orbitrap XL ${ }^{\text {TM }}$ Fourier transform mass spectrometer (FTMS), equipped with an ESI ION MAX ${ }^{\mathrm{TM}}$ source (Thermo-Fisher, San Josè, CA, USA).

A $5 \mu \mathrm{m}$ TSK-gel Amide- $80^{\circledR}$ column $(250 \times 2.0 \mathrm{~mm}$ i.d.) (Tosoh Bioscience LLC, 156 Keystone Drive, Montgomeryville, PA, USA) was eluted isocratically at $0.2 \mathrm{~mL} / \mathrm{min}$ with $65 \% \mathrm{~B}$. Eluent A was water and B was a $95 \%$ acetonitrile/water solution, both eluents contained $2.0 \mathrm{mM}$ ammonium formate and 3.6 mM formic acid (pH 3.5) [36]. The injection volume was $5 \mu \mathrm{L}$.

LC-HRMS analyses were performed in the positive ion mode, in collision induced dissociation (CID) $\mathrm{MS}^{2}$ experiments, by using the following source settings: spray voltage $=4.2 \mathrm{kV}$, capillary temperature $=440{ }^{\circ} \mathrm{C}$, capillary voltage $=29 \mathrm{~V}$, sheath gas $=35$ and auxiliary gas $=10$ (arbitrary units), tube lens voltage $=70 \mathrm{~V}$. In all experiments, a 30,000 resolving power was used. Full scan (FS) spectra were collected in the mass range $m / z$ 200-500, MS/MS spectra were acquired by using the parameters reported in able 1, with an activation Q of 0.250 , and an activation time of $30 \mathrm{~ms}$. Extracted ion chromatograms (XIC) were obtained from MS/MS spectra by selecting fragment ions reported in Table 1 and used for quantification versus PSP toxin standards.

Table 1. Precursor ion, formula, mass range, and collision energy (\%), used in the chemical analyses, and limit of detection (LOD) and quantification (LOQ) measured.

\begin{tabular}{|c|c|c|c|c|c|c|}
\hline Toxin & $\begin{array}{c}\text { Precursor } \\
\operatorname{Ion}(m / z)\end{array}$ & Formula & $\begin{array}{c}\text { Product Ion } \\
(\mathrm{m} / \mathrm{z})\end{array}$ & $\begin{array}{c}\text { Collision Energy } \\
\text { (CE) \% }\end{array}$ & $\begin{array}{c}\text { LOD } \\
(\mathrm{ng} / \mathrm{mL})\end{array}$ & $\begin{array}{c}\text { LOQ } \\
\text { (ng/mL) }\end{array}$ \\
\hline GTX1/4 & 332.1 & {$\left[\mathrm{M}+\mathrm{H}-\mathrm{SO}_{3}\right]^{+}$} & $\begin{array}{l}314.1204 \\
253.1041\end{array}$ & 20 & $5 / 30$ & $11 / 56$ \\
\hline STX & 300.1 & {$[\mathrm{M}+\mathrm{H}]^{+}$} & $\begin{array}{l}282.1311 \\
221.1143 \\
204.0877\end{array}$ & 22 & 21 & 40 \\
\hline B1 & 300.1 & {$\left[\mathrm{M}+\mathrm{H}-\mathrm{SO}_{3}\right]^{+}$} & $\begin{array}{l}282.1311 \\
221.1143 \\
204.0877\end{array}$ & 22 & 43 & 86 \\
\hline deSTX & 257.1 & {$[\mathrm{M}+\mathrm{H}]^{+}$} & $\begin{array}{l}239.1255 \\
222.0984 \\
180.0765\end{array}$ & 24 & 37 & 70 \\
\hline GTX2/3 & 316.1 & {$\left[\mathrm{M}+\mathrm{H}-\mathrm{SO}_{3}\right]^{+}$} & $\begin{array}{l}298.1254 \\
220.0824\end{array}$ & 21 & $40 / 30$ & $78 / 60$ \\
\hline $\mathrm{C} 1 / 2$ & 316.1 & {$\left[\mathrm{M}+\mathrm{H}-2 \mathrm{SO}_{3}\right]^{+}$} & 298.1254 & 21 & $23 / 28$ & $47 / 60$ \\
\hline NEO & 316.1 & {$[\mathrm{M}+\mathrm{H}]^{+}$} & $\begin{array}{l}298.1254 \\
220.0824\end{array}$ & 21 & 9 & 18 \\
\hline dcGTX $2 / 3$ & 273.1 & {$\left[\mathrm{M}+\mathrm{H}-\mathrm{SO}_{3}\right]^{+}$} & $\begin{array}{l}255.1201 \\
238.0933\end{array}$ & 25 & $71 / 60$ & $140 / 130$ \\
\hline dcNEO & 273.1 & {$[\mathrm{M}+\mathrm{H}]^{+}$} & 255.1201 & 25 & 70 & 140 \\
\hline
\end{tabular}


Calculation of elemental formulae was performed by using the mono-isotopic ion peak of each ion cluster. A mass tolerance of $5 \mathrm{ppm}$ was used and the isotopic pattern of each ion cluster was considered. For each PSP toxin, the limit of detection (LOD) was measured and corresponded to the lowest concentration level that can be determined at $3<\mathrm{S} / \mathrm{N}$ ratio $<10$. Limit of quantification (LOQ) was measured and corresponded to the lowest concentration level that can be determined at $\mathrm{S} / \mathrm{N}$ ratio $>10$ (Table 1).

\subsubsection{Matrix Effect}

An A. minutum sample, containing only GTX1/4, was spiked with a pure GTX2/3 standard to obtain a concentration level of $63 \mathrm{ng} / \mathrm{mL}$. Matrix effect was calculated by comparing the peak area of the matrix matched (MM) standard with that of a matrix free (MF) GTX2/3 standard.

The ion suppression or enhancement effect was assessed as: 100 - (peak area of MM standard/peak area of MF standard) $\times 100$.

\subsection{RNA Extraction and Reverse-Transcription}

Each strain was analysed for absolute and relative quantification of $s x t A$ and $s x t G$ mRNAs content. RNA was extracted from $3.0 \times 10^{6}$ cells at different growth phases using TRIzol Reagent (Ambion, Life Technologies, Carlsbad, CA, USA) following manufacturer's instructions with few modifications: cell lysis was performed at $60 \pm 1{ }^{\circ} \mathrm{C}$ for $10 \mathrm{~min}$ in a water bath, and there was a 10 min shaking step with $0.5 \mathrm{~mm}$ zirconia-silica beads $(400 \mathrm{mg})$ contained in the sample tube. The resulting RNA pellet was dissolved in $100 \mu \mathrm{L}$ RNAse-free water and purified with the RNeasy mini kit (Qiagen, Hilden, Germany) including on-column DNase digestion with the RNase-Free DNase Set (Qiagen, Hilden, Germany). Finally, RNA was eluted with $40 \mu \mathrm{L}$ RNase-free water. The concentration, integrity and purity of RNA was tested with a PharmaSpec UV-1700 spectrophotometer (Shimadzu, Kyoto, Japan), measuring absorbance at 260, 280 and $230 \mathrm{~nm}$, and with electrophoresis analysis in an agarose gel. Only samples with intact RNA were taken into account for reverse-transcription and qPCR. The purified RNA (900 ng) was spiked with $100 \mathrm{ng}$ of human RNA derived from human MCF7 cells, to be used as an exogenous reverse transcription control. The cDNA was prepared using SuperScript ${ }^{\circledR}$ III First-Strand Synthesis SuperMix for qRT-PCR (Invitrogen, Life Technologies, Carlsbad, CA, USA).

\subsection{Primer Design and $q P C R$ Conditions}

The primers were designed using Primer Express 2.0 software (Applied Biosystems, Life Technologies, Carlsbad, CA, USA). The sequences used for designing primers specific for genes of interest were: a long isoform precursor mRNA of sxtA (GenBank Accession number: JF343268) and mRNA sxtG (GenBank Accession number: JX995121) both from Alexandrium minutum CCMP113. These primers and condition were used for amplification of both cDNA and genomic DNA for assessing the presence of target sequence in the strain genomes. Experiments that gave a negative result were repeated by including within the same reaction 100 copies of purified PCR product as a positive control in order to verify the absence of inhibition. 
The actin and 5.8S RNA genes were initially considered as housekeeping genes (HKG). However, due to their significant differences in expression observed at the different growth phases, the human $\beta 2 \mathrm{M}$ gene was used as a control for relative quantification of $s x t A$ and $s x t G$ expression, and to check the reproducibility and efficiency of reverse transcription. The actin primers were designed using the A. minutum actin gene as reference (JN402307). The specificity of all primers was examined in silico using BLAST. The primers specific for 5.8S RNA were 5.8S3' and 5.8S5' [53]. The primers $\beta 2 \mathrm{M} f$ and $\beta 2 \mathrm{M} \mathrm{r}$ specific for human $\beta 2$-microglobulin were from [54].

The primer sequences and concentrations used in each qPCR reaction are shown in Table 2. The qPCR protocols were performed on a StepOne Real-time PCR system (Applied Biosystems, LifeTechnologies, Carlsbad, CA, USA) and have been optimized in order to obtain reaction efficiencies close to $100 \%$. Reactions were run in $25 \mu \mathrm{L}$ volumes with Hot-Rescue Real-Time PCR Kit-SG Mix $(1 \times)$ containing Sybr Green (Diatheva, Fano, Italy). All qPCR amplification protocols started with a 10 min activation step at $95{ }^{\circ} \mathrm{C}$, followed by 40 cycles including $15 \mathrm{~s}$ at $95{ }^{\circ} \mathrm{C}$, and $1 \mathrm{~min}$ at $60{ }^{\circ} \mathrm{C}$ for annealing and extension. The qPCRs were followed by a dissociation protocol from $60{ }^{\circ} \mathrm{C}-95^{\circ} \mathrm{C}$ and melting curve analysis. All samples were run in three biological replicates and each of those were run with two technical replicates.

Table 2. Primers designed in this study or previously developed including optimized final concentrations for the real-time PCR assay.

\begin{tabular}{ccc}
\hline Primers & Sequences 5' $\rightarrow \mathbf{3}^{\prime}$ & Concentration \\
\hline sxtA1 alex. F & GCAGCGATGCTACTCCTACTACGT & $600 \mathrm{nM}$ \\
sxtA1 alex. R & TCGAAGAKGATGCKGTGGTACCT & $600 \mathrm{nM}$ \\
\hline sxtG F & CCGGGCCGTGAAGGAT & $600 \mathrm{nM}$ \\
sxtG R & TGTGGCTCGTCGATTTCGA & $600 \mathrm{nM}$ \\
\hline Act a.min upp. & AGATTGTGCGCGATGTCAAGG & $400 \mathrm{nM}$ \\
Act a.min low. & CGCCGTGATGATGATTCCCTC & $400 \mathrm{nM}$ \\
\hline 5.8S 3' & \multirow{2}{*}{ 53] } & $400 \mathrm{nM}$ \\
5.8S 5' & \multirow{2}{*}{ [54] } & $400 \mathrm{nM}$ \\
\hline B2M F & & $200 \mathrm{nM}$ \\
B2M R & & $200 \mathrm{nM}$ \\
\hline
\end{tabular}

The standard curves were constructed from a six point ten-fold dilution series of purified sxtAl and $s x t G$ PCR products (from 2 to $1.0 \times 10^{6}$ copies) generated from DNA of $A$. minutum AMI2OL. The PCR product was purified with the MinElute Gel Extraction Kit (Qiagen, Hilden, Germany) and quantified with a Qubit (Invitrogen, LifeTechnologies, Carlsbad, CA, USA). The amplification efficiency of the qPCR assays was estimated from standard curves using the StepOne software version 2.3 (Applied Biosystems, LifeTechnologies, Carlsbad, CA, USA).

\subsection{Nutrient Analyses}

Chemical analyses of dissolved inorganic nutrients $\left(\mathrm{N}-\mathrm{NO}_{3}, \mathrm{~N}-\mathrm{NO}_{2}, \mathrm{~N}-\mathrm{NH}_{4}\right.$ and $\left.\mathrm{P}-\mathrm{PO}_{4}\right)$ in culture supernatants filtered on $0.45 \mu \mathrm{m}$ nitrocellulose filters (Millipore, Temecula, CA, USA) were performed following the method of [55] using a Shimadzu spectrophotometer (mod. UV-1700). 
Dissolved inorganic nitrogen (DIN) was expressed as $\mathrm{NO}_{3}^{-}+\mathrm{NO}_{2}^{-}+\mathrm{NH}_{4}^{+}$and dissolved inorganic phosphate (DIP) was expressed as $\mathrm{P}-\mathrm{PO}_{4}$.

\subsection{Statistical Analyses}

Shapiro-Wilk test was used to check the lack of normality of data. Therefore, the nonparametric tests Mann-Whitney and Kruskal-Wallis were used for the comparison of median among strains and growth phases, for gene expression data and the determination of toxin intracellular contents. The Spearman's test was used for the correlation between levels of gene expression and intracellular content of toxins. All tests were obtained with PAST ver. 2.09 [56] with a $p<0.05$ determining significance.

\section{Conclusions}

This is the first study on sxtAl and $\operatorname{stx} G$ gene expression and their correlation with toxin content in Mediterranean A. minutum. The expression levels and intracellular toxin accumulation were studied in A. minutum strains grown in enriched medium and nutrient limitation. In standard medium conditions, A. minutum produced exclusively GTX1/4 and the toxin production decreased from exponential to the stationary phase. Despite both the $s x t A 1$ gene expression and intracellular toxin content showing a reduction in trend from exponential to stationary phase, this correlation was not significant. The $\operatorname{sxt} G$ gene was detected in only two strains. The gene expression followed the same trend of the sxtAl, but the absolute mRNA quantity was not correlated with either toxins or with sxtA1. Under phosphorus or nitrogen limitation, the toxin content displayed a significant reduction in the A. minutum CBA57 only. Also in these nutrient depleted conditions, the correlation between gene expression and toxin was not significant.

Hence, the monitoring of expression level of $\operatorname{sxtAl}$ and $\operatorname{sxt} G$ did not appear sufficient to predict toxicity in Mediterranean A. minutum. It would be necessary to increase knowledge regarding the expression and function of other genes involved in the PST biosynthesis pathway to improve the ecological interpretation of toxin production, as well as to provide the possibility of using new molecular markers for the monitoring of toxin presence in seawater and accumulation in farmed shellfish.

\section{Acknowledgments}

We would like to thank Silvia Casabianca for helpful suggestions during the revision of the manuscript. This work was supported by funding from Projects PRIN2009 and PNR2010 from MIUR, and ENPI CBC Mediterranean Sea Basin Programme (M3-HABs Project).

\section{Author contributions}

F.P. and A.P. designed the experiments. F.P. designed the primers. F.P., F.R., E.D.I., L.T. performed the laboratory work. F.P., L.G. A.P., C.D.A, P.C., E.D.I., L.T. M.F. wrote the manuscript.

\section{Conflicts of Interest}

The authors declare no conflict of interest. 


\section{References}

1. Taylor, F.J.R. General group characteristics, special features of interest, short history of dinoflagellate study. In The Biology of Dinoflagellates. Botanical Monographs; Taylor, F.J.R., Ed.; Blackwell Scientific Publications: Oxford, UK, 1987; Volume 21, p. 798.

2. Wisecaver, J.H.; Hackett, J.D. Dinoflagellate genome evolution. Ann. Rev. Microbiol. 2011, 65, 369-387.

3. Davy, S.K.; Allemand, D.; Weis, V.M. Cell biology of cnidarian-dinoflagellate symbiosis. Microbiol. Mol. Biol. Rev. 2012, 76, 229-261.

4. Hallegraeff, G.M. A review of harmful algal blooms and their apparent global increase. Phycologia 1993, 32, 79-99.

5. Daranas, A.H.; Norte, M.; Fernández, J.J. Toxic marine microalgae. Toxicon 2001, 39, 1101-1132.

6. Hallegraeff, G.M. Harmful algal blooms: A global overview. In Manual on Harmful Marine Microalgae; Hallegraeff, G.M., Anderson, D.M., Cembella, A.D., Eds.; UNESCO: Paris, France, 1995; Volume 33, pp. 1-22.

7. Wang, D.Z. Neurotoxins from marine dinoflagellates: A brief review. Mar. Drugs 2008, 6, 349-731.

8. Rein, K.S.; Borrone, J. Polyketides from dinoflagellates: Origins, pharmacology and biosynthesis. Comp. Biochem. Physiol. B Biochem. Mol. Biol. 1999, 124, 117-131.

9. Satake, M.; Murata, M.; Yasumoto, T.; Fujita, T.; Naoki, H. Amphidinol, a polyhydroxypolyene antifungal agent with an unprecedented structure, from a marine dinoflagellate, Amphidinium klebsii. J. Am. Chem. Soc. 1991, 113, 9859-9861.

10. Deeds, J.R.; Landsberg, J.H.; Etheridge, S.M.; Pitcher, G.C.; Longan, S.W. Non-Traditional vectors for paralytic shellfish poisoning. Mar. Drugs 2008, 6, 308-348.

11. Wiese, M.; D’Agostino, P.M.; Mihali, T.K.; Moffitt, M.C.; Neilan, B.A. Neurotoxic alkaloids: Saxitoxin and its analogs. Mar. Drugs 2010, 8, 2185-2211.

12. Smith, J.L.; Boyer, G.L.; Zimba, P.V. A review of cyanobacterial odorous and bioactive metabolites: Impacts and management alternatives in aquaculture. Aquaculture 2008, 280, 5-20.

13. Orr, R.J.S.; Stüken, A.; Rundberget, T.; Eikrem, W.; Jakobsen, K.S. Improved phylogenetic resolution of toxic and non-toxic Alexandrium strains using a concatenated rDNA approach. Harmful Algae 2011, 10, 676-688.

14. Anderson, D.M.; Alpermann, T.J.; Cembella, A.D.; Collos, Y.; Masseret, E.; Montresor, M. The globally distributed genus Alexandrium: Multifaceted roles in marine ecosystems and impacts on human health. Harmful Algae 2012, 14, 10-35.

15. Penna, A.; Fraga, S.; Masó, M.; Giacobbe, M.G.; Bravo, I.; Garcés, E.; Vila, M.; Bertozzini, E.; Andreoni, F.; Luglié, A.; et al. Phylogenetic relationships among the Mediterranean Alexandrium (Dinophyceae) species based on sequences of 5.8S gene and Internal Transcript Spacers of the rRNA operon. Eur. J. Phycol. 2008 43, 163-178.

16. Touzet, N.; Franco, J.M.; Raine, R. Morphogenetic diversity and biotoxin composition of Alexandrium (Dinophyceae) in Irish coastal waters. Harmful Algae 2008 7, 782-797. 
17. Lim, P.-T.; Sato, S.; van Thuoc, C.; The Tu, P.; Thi Minh Huyen, N.; Takata, Y.; Yoshida, M.; Kobiyama, A.; Koike, K.; Ogata, T. Toxic Alexandrium minutum (Dinophyceae) from Vietnam with new gonyautoxin analogue. Harmful Algae 2007, 6, 321-331.

18. Dell'Aversano, C.; Walter, J.A.; Burton, I.W.; Stirling, D.J.; Fattorusso, E.; Quilliam, M.A. Isolation and structure elucidation of new and unusual saxitoxin analogues from mussels. $J$. Nat. Prod. 2008, 71, 1518-1523.

19. Kellmann, R.; Mihali, T.K.; Jeon, Y.J.; Pickford, R.; Pomati, F.; Neilan, B.A. Biosynthetic intermediate analysis and functional homology reveal a saxitoxin gene cluster in cyanobacteria. Appl. Environ. Microbiol. 2008, 74, 4044-4053.

20. Mihali, T.K.; Kellmann, R.; Neilan, B.A. Characterisation of the paralytic shellfish toxin biosynthesis gene clusters in Anabaena circinalis AWQC131C and Aphanizomenon sp. NH-5. BMC Biochem. 2009, 10, doi:10.1186/1471-2091-10-8.

21. Moustafa, A.; Loram, J.E.; Hackett, J.D.; Anderson, D.M.; Plumley, F.G.; Bhattacharya, D. Origin of saxitoxin biosynthetic genes in cyanobacteria. PLoS One 2009, 4, e5758.

22. Stucken, K.; John, U.; Cembella, A.; Murillo, A.A.; Soto-Liebe, K.; Fuentes-Valdés, J.J.; Friedel, M.; Plominsky, A.M.; Vásquez M.; Glöckner, G. The smallest known genomes of multicellular and toxic cyanobacteria: Comparison, minimal gene sets for linked traits and the evolutionary implications. PLoS One 2010, 5, e9235.

23. Mihali, T.K.; Carmichael, W.W.; Neilan, B.A. A putative gene cluster from a Lyngbya wollei bloom that encodes paralytic shellfish toxin biosynthesis. PLoS One 2011, 6, e14657.

24. Smith, F.M.J.; Wood, S.A.; van Ginkel, T.; Broady, P.A.; Gaw, S. First report of saxitoxin production by a species of the freshwater benthic cyanobacterium, Scyttonema Agardh. Toxicon 2011, 57, 566-573.

25. Gupta, S.; Norte, M.; Shimizu, Y. Biosynthesis of saxitoxin analogues: The origin and introduction mechanism of the side-chain carbon. J. Chem. Soc. Chem. Commun. 1989, 19, 1421-1424.

26. Shimizu, Y. Microalgal metabolites. Chem. Rev. 1993, 93, 1685-1698.

27. Kellmann, R.; Stüken, A.; Orr, R.J.S.; Svendsen, H.M.; Jakobsen, K.S. Biosynthesis and molecular genetics of polyketides in marine dinoflagellates. Mar. Drugs 2010, 8, 1011-1048.

28. Yang, I.; John, U.; Beszteri, S.; Glöckner, G.; Krock, B.; Goesmann, A.; Cembella, A.D. Comparative gene expression in toxic versus non-toxic strains of the marine dinoflagellate Alexandrium minutum. BMC Genomics 2010, 11, doi:10.1186/1471-2164-11-248.

29. Stüken, A.; Orr, R.J.S.; Kellmann, R.; Murray, S.A.; Neilan, B.A.; Kjetill, S.J. Discovery of nuclear-encoded genes for the neurotoxin saxitoxin in dinoflagellates. PLoS One 2011, e0020096.

30. Kellmann, R.; Neilan, B.A. Biochemical characterization of paralytic shellfish toxin biosynthesis in vitro. J. Phycol. 2007, 43, 497-508.

31. Orr, R.J.S.; Stüken, A.; Murray, S.A.; Jakobsen, S.K. Evolutionary acquisition and loss of saxitoxin biosynthesis in dinoflagellates: The Second "Core" Gene, sxtG. Appl. Environ. Microbiol. 2013, 79, 2128-2136.

32. Guisande, C.; Frangópulos, M.; Maneiro, I.; Vergara, A.R.; Riveiro, I. Ecological advantages of toxin production by the dinoflagellate Alexandrium minutum under phosphorus limitation. Mar. Ecol. Prog. Ser. 2002, 225, 169-176. 
33. Lippemeier, S.; Frampton, D.M.F.; Blackburn, S.I.; Geier, S.C.; Negri, A.P. Influence of phosphorus limitatio on toxicity and photosynthesis of Alexandrium minutum (dinophyceae) monitored by in-line detection of variable chlorophyll fluorescence. J. Phycol. 2003, 38, 320-331.

34. Frangópulos, M.; Guisande, C.; de Blas, E.; Maneiro, I. Toxin production and competitive abilities under phosphorus limitation of Alexandrium species. Harmful Algae 2004, 3, 131-139.

35. Touzet, N.; Franco, J.M.; Raine, R. Influence of inorganic nutrition on growth and PSP toxin production of Alexandrium minutum (Dinophyceae) from Cork Harbour, Ireland. Toxicon 2007, 50, 106-119.

36. Dell'Aversano, C.; Hess, P.; Quilliam, M.A. Hydrophilic interaction liquid chromatography-mass spectrometry for the analysis of paralytic shellfish poisoning (PSP) toxins. J. Chromatogr. A 2005, 1081, 190-201.

37. Cembella, A.D.; Sullivan, J.J.; Boyer, G.L.; Taylor, F.J.R.; Andersen, R.J. Variation in paralytic shellfish toxin composition within the Protogonyaulax tamarensis/catenella species complex; red tide dinoflagellates. Biochem. Syst. Ecol. 1987, 15, 171-186.

38. Anderson, D.M.; Kulis, D.M.; Sullivan, J.J.; Hall, S.; Lee, C. Dynamics and physiology of saxitoxin production by the dinoflagellates Alexandrium spp. Mar. Biol. 1990, 104, 511-524.

39. Cembella, A.D. Ecophysiology and metabolism of paralytic shellfish toxins in marine microalgae. In Physiological Ecology of Harmful Algal Blooms; Anderson, D.M., Cembella, A.D., Hallegraeff, G.M. Eds.; Springer: Berlin, Germany, 1998; pp. 381-403.

40. Yang, I.; Beszteri, S.; Tillmann, U.; Cembella, A.; John U. Growth- and nutrient-dependent gene expression in the toxigenic marine dinoflagellate Alexandrium minutum. Harmul. Algae 2011, 12, $55-69$.

41. Béchemin, C.; Grzebyk D.; Hachame F.; Hummert C.; Maesrini, S.Y. Effect of different nitrogen/phosphorus nutrient ratios on the toxin content in Alexandrium minutum. Aquat. Microb. Ecol. 1999, 20, 157-165.

42. Murray, S.A.; Mihali, T.K.; Neilan, B.A. Extraordinary conservation, gene loss, and positive selection in the evolution of an ancient neurotoxin. Mol. Biol. Evol. 2011, 28, 1173-1182.

43. Shimizu, Y. Microalgal metabolites: A new perspective. Annu. Rev. Microbiol. 1996, 50, 431-465

44. Hackett, J.D.; Wisecaver, J.H.; Brosnahan, M.L.; Kulis, D.M.; Anderson, D.M.; Bhattacharya, D.; Plumley, F.G.; Erdner, D.L. Evolution of saxitoxin synthesis in cyanobacteria and dinoflagellates. Mol. Biol. Evol. 2013, 30, 70-78.

45. Salcedo, T.; Upadhyay, R.J.; Nagasaki, K.; Bhattacharya, D. Dozens of toxin-related genes are expressed in a nontoxic strain of the dinoflagellate Heterocapsa circularisquama. Mol. Biol. Evol. 2012, 29, 1503-1506.

46. Maestrini, S.Y.; Bechemin, C.; Grzebyk, D.; Hummert, C. Phosphorus limitation might promote more toxin content in the marine invader dinoflagellate Alexandrium minutum. Plank. Biol. Ecol. 2000, 47, 7-11.

47. Selander, E.; Cervin, G.; Pavia, H. Effect of nitrate and phosphate on grazer-induced toxin production in Alexandrium minutum. Limnol. Oceanogr. 2008, 53, 523-530.

48. Casabianca, S.; Penna, A.; Pecchioli, E.; Jordi, A.; Basterretxea, G.; Vernesi, C. Population genetic structure and connectivity of the harmful dinoflagellate Alexandrium minutum in the Mediterranean Sea. Proc. R. Soc. B 2012, 279, 129-138. 
49. Penna, N.; Capellacci, S.; Ricci, F. The influence of the Po River discharge on phytoplankton bloom dynamics along the coastline of Pesaro (Italy) in the Adriatic Sea. Mar. Poll. Bull. 2004, 48, 321-326.

50. Vila, M.; Giacobbe, M.G.; Masó, M.; Gangemi, E.; Penna, A.; Sampedro, N.; Azzaro, F.; Camp, J.; Galluzzi, L. A comparative study on recurrent blooms of Alexandrium minutum in two Mediterranean coastal areas. Harmful Algae 2005, 4, 673-695

51. Guillard, R.R.L. Culture of phytoplankton for feeding marine invertebrates. In Culture of Marine Invertebrate Animals; Smith, W.L., Chanley, M.H., Eds.; Plenum Press: New York, NY, USA, 1975; pp. 29-60.

52. Utermöhl, H. Zur Vervollkommnung der quantitativen Phytoplankton-Methodik. Mitt. Int. Ver. Theor. Angew. Limnol. 1958, 9, 1-38.

53. Galluzzi, L.; Penna, A.; Bertozzini, E.; Giacobbe, M.G.; Vila, M., Garcés, E.; Prioli, S.; Magnani, M. Development of a qualitative PCR method for the Alexandrium spp. (Dinophyceae) detection in contaminated mussels (Mytilus galloprovincialis). Harmful Algae 2005, 4, 973-983.

54. Brandi, G.; Fraternale, A.; Lucarini, S.; Paiardini, M.; de Santi, M.; Cervasi, B.; Paoletti, M.F.; Galluzzi, L.; Duranti, A.; Magnani, M. Antitumoral activity of indole-3-carbinol cyclic tri- and tetrameric derivatives mixture in human breast cancer cells: In vitro and in vivo studies. Anti-Cancer Agents Med. Chem. 2013, 13, 654-662.

55. Strickland, J.D.H.; Parsons, T.R. A Practical Handbook of Seawater Analysis, 2nd ed.; Fisheries Research Board on Canada: Ottawa, Canada, 1972; pp. 311.

56. Hammer, Ø.; Harper, D.A.T.; Ryan, P.D. PAST: Paleontological statistics software package for education and data analysis. Palaeon. Electr. 2001, 4, 9.

(C) 2014 by the authors; licensee MDPI, Basel, Switzerland. This article is an open access article distributed under the terms and conditions of the Creative Commons Attribution license (http://creativecommons.org/licenses/by/4.0/). 